Gabriela BUJALSKA*

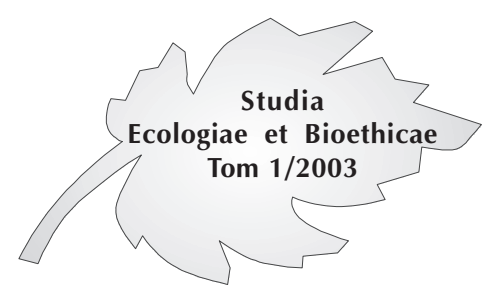

\title{
Badania nad liczebnością wyspowej populacji nornicy rudej (Clethrionomys glareolus, Schreber 1780) i ich znaczenie dla teorii
}

Liczebność zwierząt - rozumiana często jako ich obfitość - zwróciła uwagę człowieka już wówczas, gdy jako wędrowny myśliwy zabiegał o pozyskanie pokarmu. A także później - gdy prowadził życie osiadłe i jego zbiory były niszczone przez plagi gryzoni. Zanim jeszcze posiadł zdolność abstrakcyjnego myślenia i wyrażania obfitości przez liczbę zauważył, że niektóre zwierzęta w pewnych latach występują "w nadmiarze", w innych zaś jest ich wyraźny niedobór. Dziś trudno sobie wyobrazić, że do takich konkluzji doszli np. Indianie, którzy jeszcze u schyłku osiemnastego wieku liczyli bizony i jelenie dziesiątkami - ale wielkości przekraczające dwie dziesiątki wyrażali jako "dużo" lub "dużo bardzo" (Thompson 1812, za Finertym 1980).

Naukowy wymiar zmian liczebności zwierząt przypisać należy Eltonowi (1924), który wraz ze swoimi współprcownikami analizował wieloletnie zapisy Hudson Bay Company Archives i pierwszy zadał, tak istotne dla późniejszych lawinowo pojawiających się opracowań: jakie są przyczyny i skutki fluktacji liczebności zwierząt? Następny krok zrobiony przez Volterrę (1926) nadał obserwacjom fluktuacji kształt matematyczny. Te fundamentalne prace otworzyły nowe perspektywy badawcze dla całej rzeszy badaczy. Powstała never ending story i jednocześnie najbardziej płodna i spektakularna dziedzina ekologii. Skupiła wokół siebie badaczy z różnych dziedzin nauk pryrodniczych: etologów, fizjologów, genetyków, demografów. Stąd już tylko krok do włączenia do badań zoogeografów, klimatologów a nawet astronomów.

Dla znalezienia odpowiedzi na dziecinnie proste pytanie postawione przez Eltona wprzągnięte zostały systemy filozoficzne (np. holizm i redukcjonizm), szkoły metodologii (od sposobu pozyskania zwierząt aż po wyrafinowane metody analiz matematycznych), ogromne zasoby wyobraźni skupione wokół różnych szkół badawczych. Niektóre spory wo-

\footnotetext{
Instytut Ekologii i Bioetyki Uniwersytetu Kardynała Stefana Wyszyńskiego w Warszawie.
} 
kół mechanizmów odpowiedzialnych za zmiany liczebności przeszły do historii - jak np. spór wokół zależnych od gęstości czynników sterujących liczebnością populacj (koncepcja Nicholsona rozwijana od roku 1933) i czynników środowiskowych nie mających nic wspólnego z gęstością populacji (Andrewartha i Birch 1954). Spór nie został rozstrzygnięty do dziś. Do dziś bowiem nie ma jednoznacznej odpowiedzi na pytanie: czy liczebność populacji jest regulowana? Nie należy tu jednak wpadać w pułapkę jaką jest naiwna interpretacja zmian liczebności towarzysząca zmianie nieodnawialnych zasobów (np. pokarmu). Wówczas bowiem możemy mówić jedynie o ograniczaniu liczebności.

Następnym zagadnieniem rozwijającym się wokół fluktuacji liczebności jest rytmiczność jej szczytów i depresji - czyli cykle populacyjne. Od czasu gdy opracowano techniki analityczne udokumentowano istnienie 3-4 letnich cykli gryzoni. Najbardziej spektakularne i szeroko opisywane są cykle lemingów na płw. Skandynawskim, czy nasze rodzime cykle norników polnych (gazetowe "plagi mysie" na polach, które ostatnio jakby nieco przygasły F.)

$\mathrm{Na}$ tak przygotowany grunt, porzypominający przedstawioną na Rys. 1 figurę natrafia badacz pragnący rozwikłać nurtujące ekologię pytania $\mathrm{z}$ kręgu liczebności populacji. Penetruje więc problem $\mathrm{w}$ wymiarze dyna-

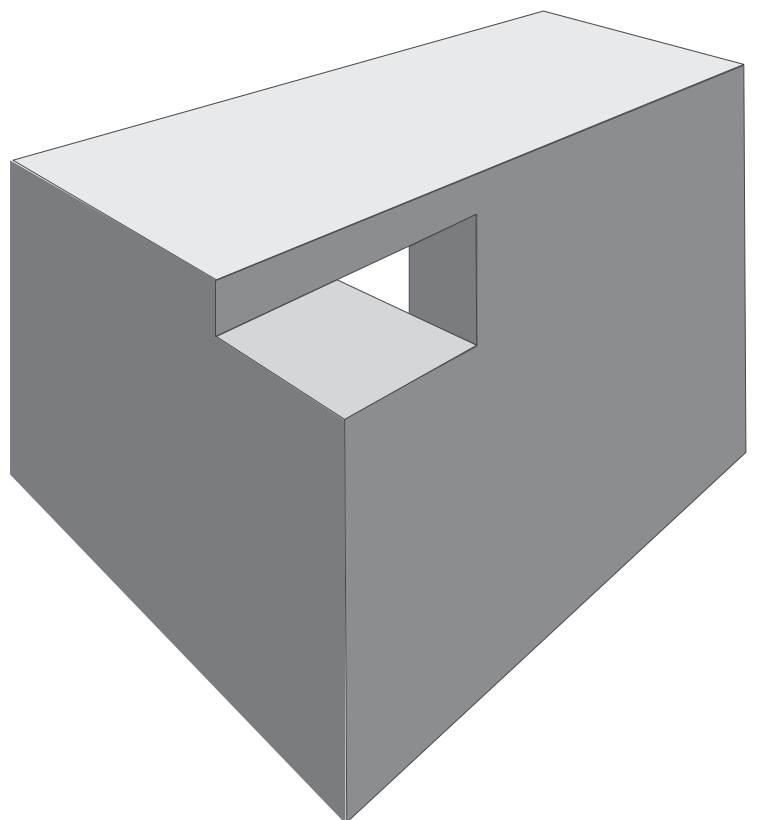

Rys. 1. Figura symbolizująca drogi dociekań naukowych - teoria budowana na ich podstawie nie zawsze jest spójna

A figure to symbolize ways of scientific inference - the theory based on those ways can be sometimes inconsistent 
miki liczebności, wiąże ją z wyróżnionymi przez siebie czynnikami, wnika w świat behawioru, szuka prawidłowości z dziedziny genetyki (metoda analizy DNA stwarza mu możliwość wgłębienia się w świat biologii molekularnej i empiryczne zbadanie prawdziwości koncepcji Chitty'ego z 1967 roku) i fizjologii. W rezultacie żmudnych dociekań, zarówno własnych, jak i całej rzeszy badaczy, buduje złożoną figurę o której do końca nie wie czy może $\mathrm{w}$ tym kształcie istnieć naprawdę - czy jest po prostu oczomlonką. Pocieszające $w$ tym wszystkim jest to, że podobne dylematy dotyczą wszystkich twórcow: tych którzy byli, są i tych którzy przyjdą po nas. I pocieszające jest to, że każdy badacz dodaje jakiś element, który wzbogaca figurę o nowy wymiar lub kształt.

Pozostaje jeszcze kwestia miejsca i czasu. Miejsca - w skali geograficznej i umiejscowienia w określonej szkole badawczej. I czasu - w skali następujących po sobie generacji badaczy, jak również czasu obserwacji. Wszystkie te elementy są istotne. Mnie samej było dane prowadzić badania w tradycjach „szkoły warszawskiej” stworzonej przez profesorów Kazimierza Tarwida i Kazimierza Petrusewicza w latach 50. ubiegłego (już!) wieku. Należy ona do kręgu filozofii holistycznej, a procesy populacyjne bada na drodze porządkowania ich względem różnych elementów struktury populacji, z których każda pełni inną funkcję. Składa się to na koncepcję organizacji populacji (Petrusewicz 1966). Oczywiste jest, że elementy tej struktury w różnych sytuacjach ekologicznych zmieniają się jak w kalejdoskopie, tworząc różne obrazy organizacji populacji. Miejscem moich przyszłych badań stała się kilkuhektarowa Wyspa Dzikiej Jabłoni na jez. Bełdany, zasiedlona przez populację nornicy rudej, Clethrionomys glareolus, (Fot. 1), a czas obserwacji trwa nieprzerwanie od 37 lat.

Zaczęło się wszystko jak wiele krótkotrwałych eksperymentów: mieliśmy $\mathrm{w}$ ciągu trzech lat odpowiedzieć na kilka pytań postawionych przez trwający właśnie Międzynarodowy Program Biologiczny, poświęcony produktywności ekosystemów. Wkrótce okazało się, że pojawiające się pytania wykraczają poza trzyletni okres obserwacji, a ja sama znalazłam się w kręgu problematyki populacyjnej i obserwując fluktuacje populacji powtórzyłam pytanie zadane przez Eltona. I zadaję je do dziś.

Ocena liczebności populacji budzi na ogół wiele trudności. Na jakimkolwiek poletku badawczym na którym znajdują się pułapki notuje się osobniki, które to poletko zamieszkują, ale także i te, które tu tylko zachodzą mieszkając w najbliższym sąsiedztwie. Powstaje tzw. „efekt krawędzi", którego skutkiem jest zawyżanie rzeczywistej liczby zwierząt. Ponadto wśród zarejestrowanych zwierząt istnieją jeszcze i takie, które tylko tędy przechodzą - są to osobniki migrujące. Tak więc już na samym wstępie badacz staje wobec trudności, które musi usunąć stosując odpowiednie metody statystyczne. Na wyspie trudności są zminimalizowane. Przede wszystkim badaniami obejmuje się całą populację, a nie tylko jej 


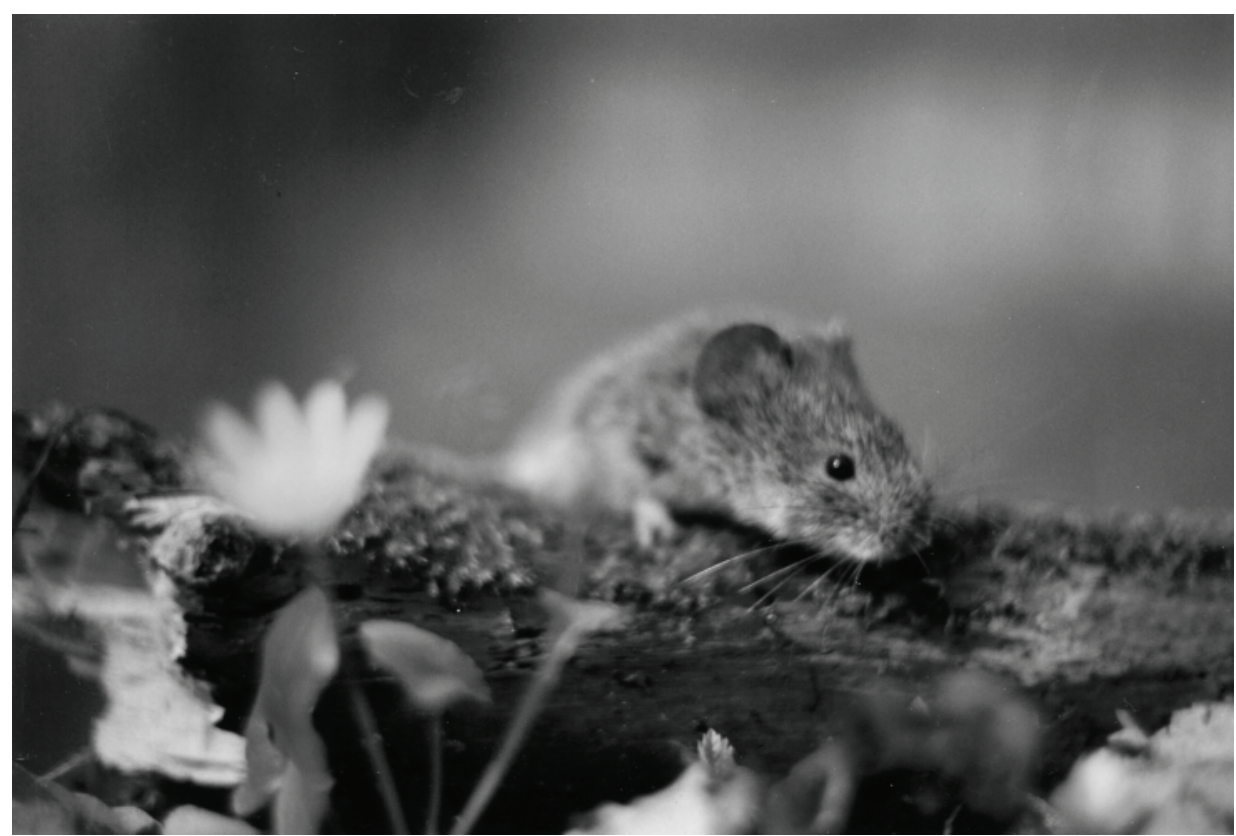

Fot. 1. Nornica ruda (fot. G. Bujalska)

The bank vole (photo G. Bujalska)

wycinek, co znacznie ułatwia wnioskowanie. Ale myliłby się ten, kto sądziłby, że trudności nie ma w ogóle!

Po pierwsze ważne jest jak długo trwa seria połowów. Ponieważ (tak jak to jest w przypadku Wyspy Dzikiej Jabłoni) stosuje się pułapki żywołowne a ocena liczebności polega na znakowaniu i liczeniu wszystkich złowionych osobników, oczywiste jest, że liczebność jest nieco wyższa niż w rzeczywistości, ponieważ część osobników ginie każdego dnia. Gdybyśmy w ten sposób (jest to tzw. metoda "spisu powszechnego" stosowana także przy spisach ludności) liczyli wszystkie nowe osobniki, które pojawiają się w pułapkach przy każdym ich przeglądzie, pod koniec roku mielibyśmy do czynienia z ogromną, nie odpowiadającą rzeczywistości liczebnością populacji. Dlatego też stosuje się krótsze serie (np. tygodniowe), w których błąd zawyżenia liczby osobników jest niewielki. Na wszelki wypadek dla sprawdzenia wielkości błędu można sięgnąć po któryś z testów korygujących błąd wynikający z przecenienia rzeczywistej liczebności populacji. Najbardziej znana jest tu metoda Jolly'ego (1965).

Dla bardziej wyrafinowanych badań konieczna jest jeszcze jedna korekta. A mianowicie, jeśli chcielibyśmy dowiedzieć się jaka jest np. struktura wiekową populacji, musimy sprawdzić, czy wszystkie osobniki mają taką samą szansę złowić się w pułapkę. Nawet pobieżna analiza wskaże, 
że tak nie jest. Starsze osobniki, lub np. samice ciężarne czy karmiące poszukujące intensywniej pokarmu w celu zaspokojenia wyższych wydatków energetycznych, łowią się częściej niż osobniki młode, które dopiero opuściły gniazda i poruszają się po niewielkiej przestrzeni. Szeroko pisze o tym Alcheikh (2001), opierając się na własnych obserwacjach z Wyspy Dzikiej Jabłoni.

Piszę o tym wszystkim dlatego aby wykazać jak ważną sprawą jest stosowana metoda badawcza, operująca informacjami zrodzonymi w czasie i przestrzeni, czy nawet co jest "biologicznie logiczne” - zmianami sezonowymi czy klimatycznymi. Takie podstawowe wyniki, na których później opiera się cała konstrukcja logiczna muszą być oparte na wyjątkowo solidnych podstawach.

Kiedy już przebrnęliśmy przez pierwsze meandry metodyczne możemy być spokojni, że liczba zarejestrowanych przez nas osobników odpowiada rzeczywistej liczbie osobników obecnych w populacji. Możemy więc zbadać jak zmieniała się liczebność populacji - zarówno w kolejnych miesiącach, jak i latach (Rys. 2). Przedstawiona tu dynamika populacji jest jedną z niewielu na świecie tak długotrwałą serią połowów i może być zaliczona do long term studies.

Pojawia się pytanie jaką przewagę nad krótkimi eksperymentami posiada ten typ danych, jeśli $w$ ogóle posiada przewagę. Już pobieżna obserwacja wskazuje, że pierwsze cztery lata potwierdziły powszechne przekonanie, że zmiany liczebności nornicy rudej zmieniają sie $\mathrm{w}$ cyklu dwuletnim (Gliwicz 1980). Jeśli jednak przyjrzymy się zmianom w następnych latach nabieramy przeświadczenia, że cykl jest dłuższy - może nawet 3-4 letni. A więc taki, jaki opisuje się dla gryzoni północnej hemisfery ( Kaikusalo 1972, Krebs i Myers 1974, Hansson 1978, Zejda 1981 i inni). Zastosowanie metody autokorelacji wzbogaconej o fourierowską transformację współczynników autokorelacji (Finerty 1980), która w sposób obiektywny ocenia długość cyklu potwierdza przypuszczenie, określając długość cyklu na 2,6 roku (Bujalska 1985). Wyliczenie to stało się możliwe, dzięki komputerowej symulacji zmian liczebności w ciągu 55 lat. Warto tu dodać, że taki empiryczny model (tkwiący korzeniami w realiach zaobserwowanych $\mathrm{w}$ populacji i wyrażonych szeregiem regresji wiążącymi je z realnym światem Wyspy) możliwy był dzięki sprzężeniu techniki komputerowej z prawidłowościami obserwowanymi w czasie 14 lat badań. Ponieważ cykl zmian liczebności mierzy się odstępami między jej szczytami, które w naszej szerokości geograficznej występują w lipcu lub wrześniu, oznacza to. że cykl liczebności wyspowej populacji nornicy rudej w latach 1966-1980 wynosił nie 2,6 roku, które są wartością średnią, a „naprawdę" występował co 2 lub 3 lata.

Tak więc wsparci wynikami wielu badaczy moglibyśmy spokojnie przyjąć, że udało się nam potwierdzić ogólnie znaną prawidłowość. Ale 


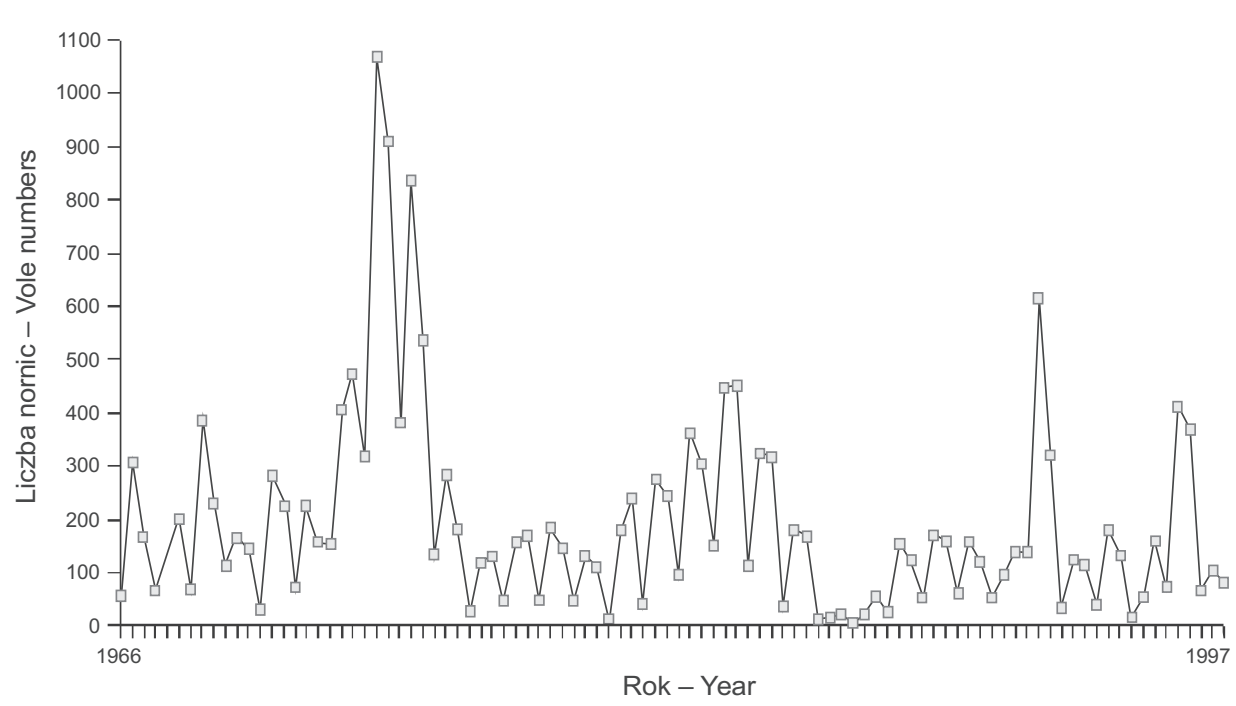

Rys. 2. Dynamika liczebności populacji nornicy rudej z Wyspy Dzikiej Jabłoni w latach 1966-1999 - przykład badań długoterminowych (według Bujalskiej 2000)

Population dynamics of bank voles inhabiting Crabapple Island in 1966-1999 - an example of long-term studies (after Bujalska 2000)

późniejsza historia badań odsłoniła przed nami nowe, zaskakujące informacje. 34-letnie badania nie wymagały już wzmocnienia przy przy pomocy symulacji - seria obserwacji była wystarczająco długa, aby można było zbadać długość cyklu. I oto okazało się, że cykl liczebności na Wyspie Dzikiej Jabłoni wynosił 3,8 roku - był to jednak cykl słabo wyrażony. Najbardziej jednak wyraźny był cykl dłuższy - 9,4 letni! (Rys. 3) (Bujalska 2000).

Przedstawione wyniki i dociekania muszą więc ustąpić przed logiką faktu. I jakkolwiek cykl liczebności "około trzyletni” może wytrzymać próbę czasu - to pojawienie się nowej informacji, znacznie wydłużającej częstość pojawiania się szczytu liczebności, rozszerza naszą wiedzę i... zmusza do dalszych badań i dyskusji. Ciekawe, że w tym samym czasie doniesiono o 9-letnim cyklu liczebności nornicy rudej w Nowosybirsku (Moshkin i in., 2000).

Istnienie cykli liczebności u gryzoni (i innych ssaków, w tym drapieżców gryzoni) stanowi jedno z najbardziej ekscytujących i poruszających wyobraźnię fenomenów demografii. Interpretacja tego zjawiska polega jednak przede wszystkim na wiązaniu liczebności populacji z innymi parametrami, które zgodnie z wiedzą ekologów mogą wpływać na kształt i tempo zmian.

Pomimo wielu prób nie udało się wyjaśnić dlaczego liczebność populacji zmienia się w cyklu wieloletnim. Na ogół są to zmiany regionalne, 


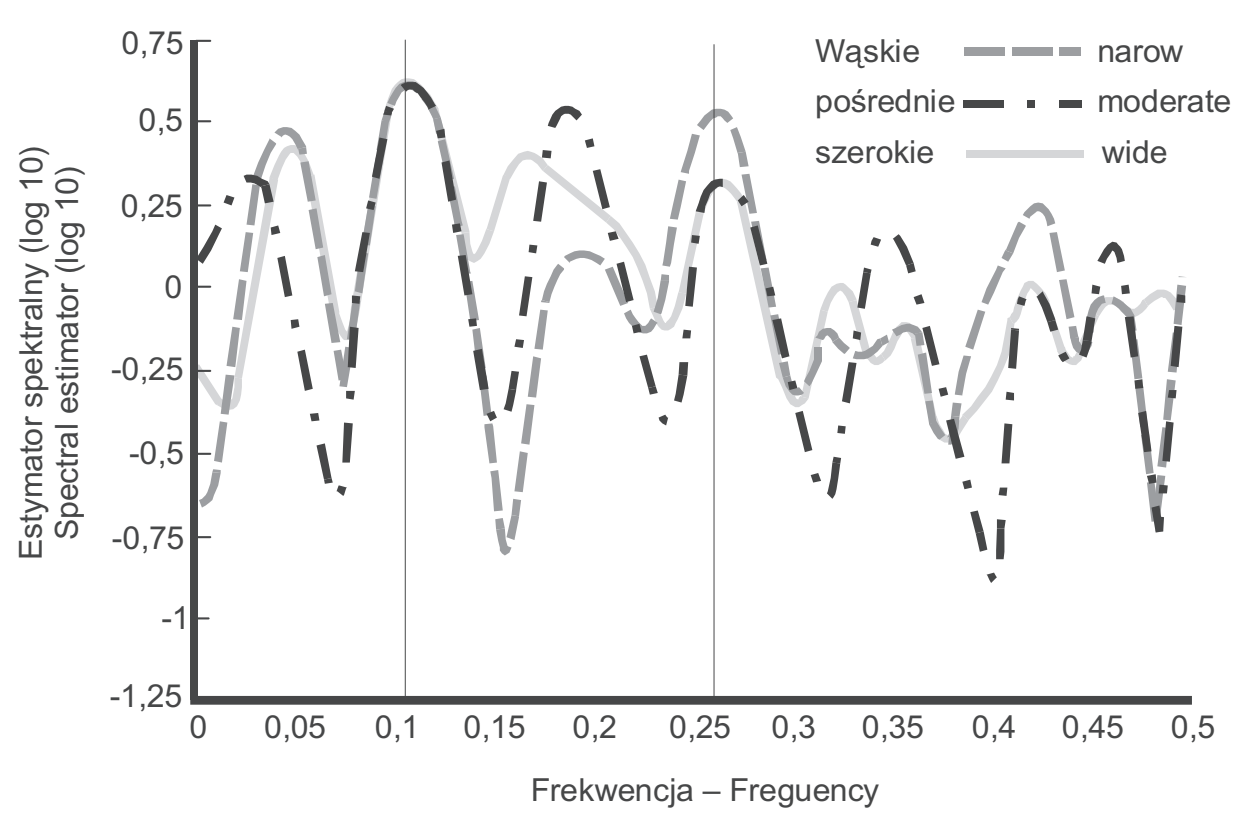

Fig. 3. Cykl liczebności populacji nornicy rudej na Wyspie Dzikiej Jabłoni w latach 1966-1999. Zbieżność szczytów trzech krzywych, reprezentujących Okna Tukey'a, przy frekwencji około 0,1 i 0,25 oznacza występowanie cykli liczebności odpowiednio o długości 9,4 oraz 3,8 roku (według Bujalskiej 2000)

Cycles of population numbers in bank voles of Crabapple Island in 1966-1999. Co-occurrence

of peaks of the three curves - representing Tukey windows - at frequencies 0.1 and 0.25 denotes cycles of the length 9.4 and 3.8 years, respectively (after Bujalska 2000)

co mogłoby wskazywać, że liczebność populacji podlega czynnikom działającym w skali regionu. Nic wię dziwnego, że uwaga badaczy kieruje się w stronę zmian klimatycznych, które modyfikując obfitość zasobów pokarmowych „pozwalają" populacji osiągnąć wyższą liczebność. O jakie zasoby jednak może chodzić? Logika pdpowiada, że jest to pokarm wysokokaloryczny, a więc nasiona. Utrzymuje się, że po latach „nasiennych”, w których produkcja nasion (np. klonu, lipy czy grabu) jest obfita - liczebność populacji jest szczególnie wysoka (Pucek i in. 1993). I jakkolwiek zgodność obu parametrów jest wysoka trudno znaleźć mechanizmy, które by tę prawidłowosć jednoznacznie wyjaśniły. Sekwencja wydarzeń: obfitszy pokarm - lepsza przeżywalność zimowa - wyższa liczebność populacji na wiosnę, wcale nie musi oznaczać, że populacja osiągnie latem szczególnie wysoką liczebność. Wiadomo bowiem, że istnieją mechanizmy, które powodują wysoki wzrost populacji gdy jej liczebność jest na początku sezonu rozrodczego bardzo niska i znacznie wolniejszy, gdy jest ona wysoka (Bujalska 1994a). Tak więc nie zawsze mechaniczne wiązanie logicznie sprzężonych czynników przekłada się na oczekiwany rezultat. 
O trudnościach podobnej ścieżki rozumowania niech świadczy fakt, że dotychchczas nie udało się stworzyć ogólnej teorii populacyjnej wyjaśniającej wieloletnie fluktuacje liczebności, która objęłaby istotne, stwierdzone empirycznie fakty i procesy. Powstające teorie - np. teoria regulacji liczebności są powszechnie akceptowane, weszły do kanonów demografii i rzadko są rewidowane. Ale przecież na liczebność popualcji spojrzeć można inaczej: nie musi ona być ",celem” , ale efektem działania procesów, operujących na drodze mechanizmów - przede wszystkim populacyjnych.

Spróbujmy więc zbudować figurę - być może podobną do przedstawionej na Rys. 1 - która wiązałaby spostrzeżenia interpretowane przez pryzmat filozofii "szkoły warszawskiej”. W tym celu należy zajrzeć do wnętrza populacji i przyjrzeć się elemetom jej struktury. W sezonie rozrodczym populacja nornicy rudej, jak zresztą i innych zwierząt, składa się z osobników dojrzałych płciowo zdolnych do rozmnażania się i ich potomstwa, które jeszcze nię osiągnęło dojrzałości płciowej. Na Wyspie Dzikiej Jabłoni liczba dojrzałych samic była ustabilizowana i - co jest szczególnie ważne dla dalszego toku rozumowania - niezależna od liczebności wszystkich samic oraz całej populacji (Rys. 3). Oznacza to, że: 1) w rozrodzie mogła uczestniczyć ograniczona liczba samic, 2) ginące dojrzałe samice były zastępowane przez inne dojrzewające i wchodzące na ich miejsce i 3) w populacji istniała rezerwa samic niedojrzałych płciowo, których dojrzewanie było zahamowane. Brzmi to niezwykle tajemniczo ale wyjaśnienie tego zjawiska jest jednak niezwykle proste.

Otóż warunkiem osiągnięcia dojrzałości płciowej przez samicę jest zdobycie określonego miejsce $\mathrm{w}$ przestrzeni nie zajętego przez inne dojrzałe samice. Jest to tzw. terytorium, stanowiące część areału osobniczego samicy. Funkcje terytorium nie są jeszcze dobrze znane, choć istnieją różne przsłanki wskazujące, że rosnące na takiej działce rośliny zapewniają pokarm przyszłemu potomstwu (Ostfeld 1990). Ale możliwa jest też inna interpretacja: terytorium jako teren wokół gniazda może być aktywnie bronione przez samicę, która chroni $\mathrm{w}$ ten sposób niesamodzielne jeszcze potomstwo (Bujalska 1991). Obie interpretacje, być może nie sprzeczne ze sobą, posiadają jednak lukę. Niezrozumiałe jest bowiem dlaczego każda dojrzała samica posiada i broni terytorium, choć tylko część $\mathrm{z}$ nich zajdzie $\mathrm{w}$ ciążę? Nie wszystkie bowiem dojrzałe samice zdążą przed śmiercią lub końcem sezonu rozrodczego wydać potomstwo. Tak więc jedno z najbardziej fundamentalnych „wynalazków” ewolucji ciągle jeszcze czeka na wyjaśnienie. Być może badania genetyczne, próba odszukania ojca lub ojców (według Ratkiewicza i Borkowskiej , którzy w 2000 roku opublikowali fascynujące rezultaty badań, u nornicy rudej spotyka się wieloojcostwo) skierują naszą uwagę na zjawiska zachodzące $\mathrm{w}$ kolonii rozrodczej i w jej sąsiedztwie. Wiążę duże nadzieje na rezultaty 
badań genetycznych (analiza DNA) z próbek zebranych w ciągu kilku lat od wszystkich osobników z populacji zasiedlającej Wyspę Dzikiej Jabłoni. Być może dowiemy się czegoś więcej na temat relacji krewniaczych $w$ koloniach rozrodczych i związków systemu socjalnego ze strukturą przestrzenną populacji.

Tak więc prosta wydawałoby się sprawa jak zmiany liczebności populacji zmusza nas do penetrowania zmian towarzyszących temu procesowi na różnych poziomach organizacji przyrody w nadziei, że uda nam się poznać jakie czynniki są za te zmiany odpowiedzialne. Pomimo wykazania, że terytorializm dojrzałych samic w sposób automatyczny hamuje dojrzewanie płciowe samic przy wysokich gęstościach populacji (gdy wszystkie wolne miejsca są zajęte przez wcześniej dojrzałe samice) często uważa się, że to właśnie zagęszczenie populacji jest bezpośrednim czynnikiem sprawczym tego zjawiska. Co więcej, ponieważ wysoka liczebność populacji obserwowana jest w drugiej połowie sezonu rozrodczego, uważa się także, że osobniki urodzone pod koniec lata lub jesienią nie są zdolne do osiągnięcia dojrzałości płciowej w roku ich urodzenia. I niby wszystkie elementy składające się na tę logiczną konstrukcję pasują do siebie nawzajem - to obraz $\mathrm{z}$ nich zbudowany nie odpowiada rzeczywistości, ponieważ koncentruje się na czynnikach ostatecznych, a nie bezpośrednich.

Wprawdzie wiele lat temu (Bujalska 1973) sprawdziłam eksperymentalnie, że samice urodzone późnym latem przy braku samic wcześniej dojrzałych (zostały one odłowione) osiągnęły dojrzałość płciową, to mimo wszystko nigdy nie udało się stwierdzić, że samice urodzone późną jesienią też są potencjalnie zdolne do osiągnięcia dojrzałości płciowej w roku ich urodzenia. Trzeba było 25 lat obserwacji aby się przekonać, że tak jest w istocie. Otóż w roku 1990 udało się zaobserwować nieprzerwany przez zimę rozród w wyspowej populacji (Bujalska 1997a). Wówczas samice urodzone pod koniec października, a nawet $\mathrm{w}$ grudniu wydały $\mathrm{w}$ środku zimy potomstwo. $\mathrm{W}$ pewnych, do dziś nie rozpoznanych warunkach, w rozmnażaniu nie przeszkadzały warunki środowiskowe, uznawane za sygnał dla hamowania rozmnażania się, czyli innymi słowy dla zakończenia sezonu rozrodczego. Ani krótki dzień, ani brak świeżego, zielonego pokarmu, ani niskie temperatury nie zdołaly powstrzymać procesu rozrodu! Wbrew wcześniejszym, przez wiele lat powtarzanym obserwacjom posiadającym rangę prawidłowości - zimowy rozród i wysoka wiosenna liczebność zaowocowały wysoką liczebnością populacji (Bujalska 1997b). O ile uboższa byłaby nasza wiedza, gdybyśmy obserwacje zakończyli rok wcześniej.

Daleka jestem od stwierdzenia, że tylko długoterminowe badania, w których badacz jest biernym obserwatorem stanowią najlapszą drogę dla poznania rzeczywistości. Wiele informacji i radości sprawia dobrze przy- 
gotowany i przeprowadzony eksperyment. Jednak aby umieć postawić Naturze pytanie, trzeba wiedzieć o co pytać. Profesor Tarwid powiadał, że na głupie pytanie Natura odpowiada złośliwie.

W opisywanej przeze mnie "historii naturalnej” wyspowej populacji nie wyeksponowałam należycie roli samców, tworząc (prawdopodobnie z racji własnej płci) obraz gynocentryczny, w którym główną rolę odgrywają samice. O samcach wiem znacznie mniej. I jakkolwiek liczba dojrzałych samców jest również ograniczana (zawsze nieco niższa niż liczba dojrzałych samic) to nie udało mi się wykazać, że one również są terytorialne. Istnieją wprawdzie przesłanki, że podział przestrzeni pomiędzy dojrzałymi samcami odbywa się na zasadzie konkurencji o dojrzałe samice (Ims 1988, Bujalska i Grüm 1989) to jednak obraz nie jest tak łatwy do interpretacji. Na ogół przypuszcza się, że samce żyją w klanach, w obrębie których ich areały wzajemnie się nakładają i bronione przed intruzami tej samej płci są jedynie granice klanu (Wiger 1982). Istnieją jednak przesłanki wskazujące, że i dojrzałe płciowo samce posiadają prawo do wyłączności posiadania własnego terytorium (Bujalska 1994b). Być może dzieje się tak w przypadku, gdy znajduje się tam aktywna płciowo samica. Wymaga to jednak dalszych badań tak istotnych dla poznania "porządku i organizacji w przyrodzie" (Ścibor-Rylska 1974).

Wróćmy teraz do zagadnienia fluktuacji liczebności populacji. Wiedza o strukturze populacji i różnych funkcjach jakie pełnią jej elementy dystansuje nas od poszukiwań przyczyn zmian liczebności w obserwacji... samej liczebności. Analiza oparta o proste relacje procesów zależnych od zagęszczenia nie jest w stanie wyjaśnić przyczyn zmian liczebności, gdyż kształtowane są one na innym poziomie organizacji populacji. To nie obfitość pokarmu wpływa bezpośrednio na liczebność populacji - działa ona poprzez pryzmat struktury przestrzennej i stosunki terytorialne dojrzałych osobników. Wzrost obfitości pokarmu pociąga za sobą zmniejszenie areałów osobniczych dojrzałych samic i więcej ich "mieści się" w określonym wycinku przestrzeni. Zwiększa się potencjał rozrodczy i więcej samic rodzi potomstwo (Bujalska 1997b).

Piszę o samicach, gdyż jak się okazało liczba samców nie zmienia się w stosunku do obserwowanej w innych latach (Bujalska 1997b). Ich areały osobnicze nie są tak "czułe" na zmiany obfitości pokarmu jak areały samic. Strategia rozrodcza samców, znajdująca swe odbicie w strukturze przestrzennej i wielkości areałów wiąże się z powiększeniem szansy spotkania jak największej liczby aktywnych płciowo samic. Różne są więc drogi samic i samców w zwiększaniu ich dostosowania (fitness) i wydania na świat jak największej liczby potomstwa. Myliłby się jednak ten, kto przypuszczałby, że wzrost areałów osobniczych samców pociąga za sobą automatycznie wzrost liczby potomstwa, na zasadzie: większy areał - więcej samic w jego obrębie. Może tak być, ale strategia ta jest bardzo kosztowna. 
Samce, które ją "wybierają" żyją krócej, niż samce o areałach mniejszych. Te pierwsze więc są być może ojcami większej liczby potomstwa, ale rodzi się ono w krótszym czasie, podczas gdy potomstwo tych drugich przychodzi na świat $w$ okresie dłuższym. Która $z$ tych strategii jest skuteczniejsza to już sprawa prawdopodobnie przypadkowych zmian środowiskowych.

Po poznaniu sposobu życia widzianego z perspektywy nornicy rudej, rozmieszczenia $\mathrm{w}$ przestrzeni i wymagań terytorialnych różnych kategorii osobników trudno wyobrazić sobie, że ich sztuka przetrwania zmierza do osiągnięcia określonej liczebności (gęstości) populacji. Proste mechanizmy porządkujące relacje między najbliższymi sąsiadami wskazują, że tu właśnie szukać należy przyczyn wzrostu i spadku liczebności calej populacji. Zgoda na przyjęcie takiego sposobu interpretacji zjawisk demograficznych onaczałaby, że liczebność populacji jest rezultatem procesów zachodzących $\mathrm{w}$ jej wnętrzu. A więc byłaby jedynie produktem ubocznym istotnych dla funkcjonowania osobników zjawisk rozgrywających się w najbliższym otoczeniu kolonii rozrodczych lub grup sąsiedzkich.

Wiele uwagi poświęciłam rozrodczości nornicy rudej. Przeżywalność druga składowa określająca liczebność populacji wymyka się spod jej kontroli, podlegając $\mathrm{w}$ znacznej mierze czynnikom niezależnym od populacji. Takim jak np. nieprzewidywalne zmiany pogody, drapieżnictwo, pasożytnictwo - $\mathrm{z}$ racji trudności $\mathrm{w}$ ich ocenie, (nieoznaczoności) zaliczanych do zjawisk przypadkowych. Nie muszę dodawać, że o przypadku zwykliśmy mówić zazwyczaj wówczas, gdy nie potrafimy rozpoznać czynnika kluczowego, decydującego o przebiegu danego procesu. Nie mniej jednak wyniki obserwacji przeżywalności wyspowej populacji wskazały na istnienie zaskakującej prawidłowowości. Otóż przeżywalność wyraźnie wzrastała wraz ze wzrostem liczebności populacji (Bujalska 1985). Nie takiego przebiegu tego procesu oczekiwałby zwolennik działania procesów zależnych od zagęszczenia i regulacji liczebności. W myśl założeń wzrostowi liczebności populacji winien towarzyszyć spadek przeżywalności (wzrost śmiertelności). W tym przypadku dodatnia zależność przeżywalności od liczebności populacji winna być interpretowana jako znaczenie wzrostu przeżywalności dla wrostu liczebności populacji, co wydaje się zjawiskiem oczywistym w łańcuchu przyczynowo-skutkowym.

Przedstawiony obraz funkcjonowania populacji, uzależnienia liczebności populacji od wewnątrzpopulacyjnych procesów, a przede wszystkim ich porządkowanie na drodze mechanizmów zapewniającym populacji trwanie $\mathrm{w}$ przestrzeni i czasie jest poglądem zaledwie stycznym do powszechnie ugruntowanego przekonania o regulacyjnym działaniu czynników zależnych od zagęszczenia. Obraz ten powstawał w miarę wzbogacania wiedzy o istocie i korzeniach ewolucyjnych chroniących populację przed wyginięciem, ale także przed przegęszczeniem. Konsekwencją stabilizacji rozrodczości jest bowiem utrzymanie liczebności populacji $\mathrm{w}$ 
A

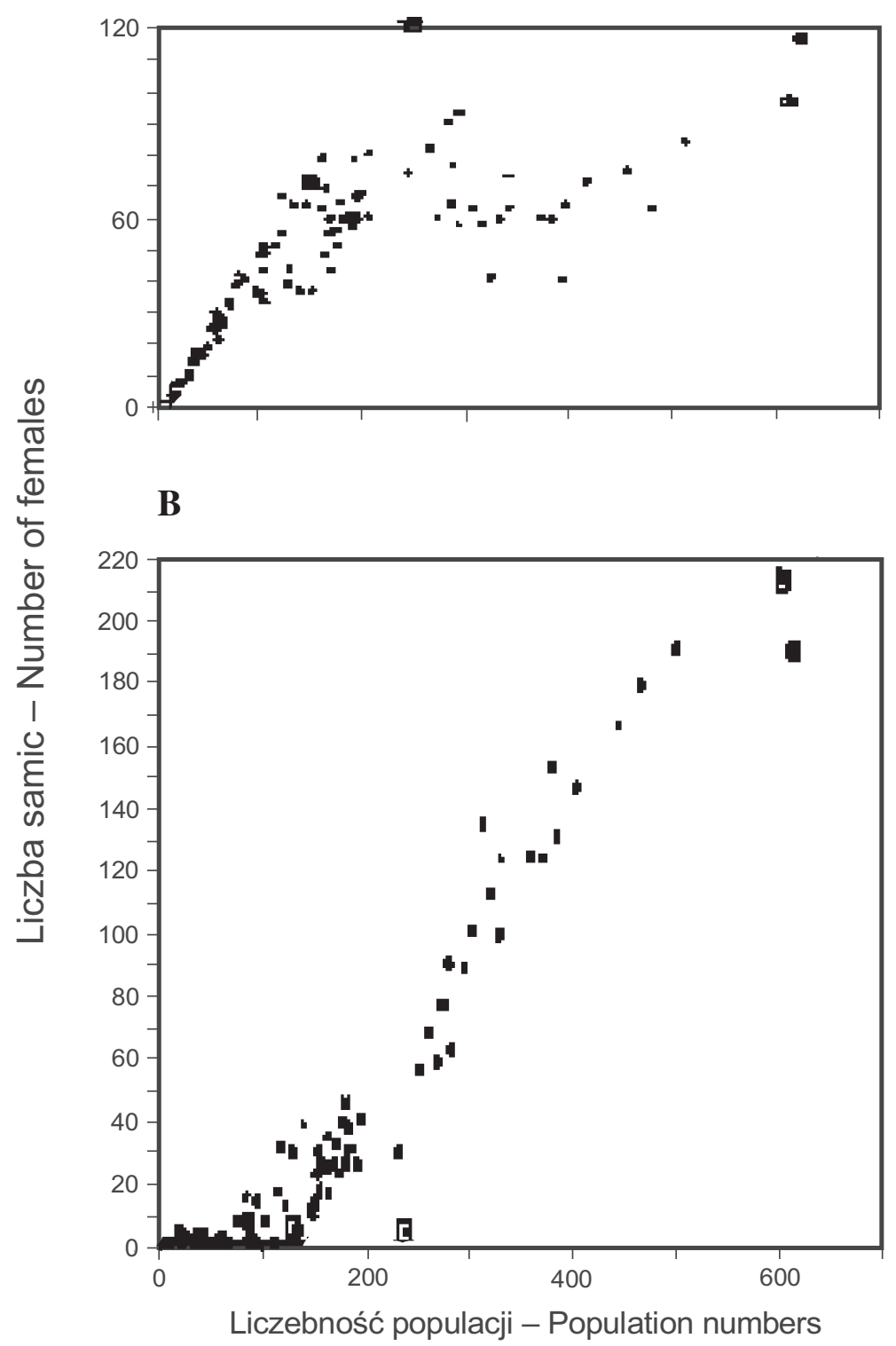

Rys. 4. Zmiany liczby samic dojrzałych (A) i niedojrzałych (B) towarzyszące wzrostowi liczebności populacji nornicy (według Bujalskiej 1997)

The changes in numbers of mature (A) and immature (B) females that accompany increase of population size of bank voles (after Bujalska 1997) 


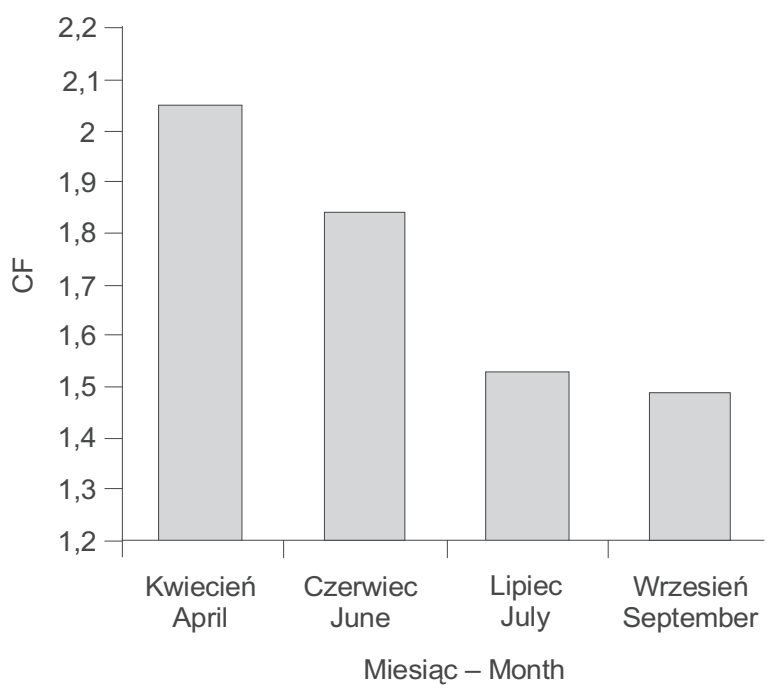

Rys. 5. Wskaźnik fluktuacji Whittakera (1975) zanotowany w populacji nornicy na Wyspie Dzikiej Jabłoni obniża się stopniowo od kwietnia do września. Wskazuje to, że liczebność populacji zmienia się w szerszych granicach na początku sezonu rozrodczego niż pod jego koniec (według Bujalskiej 1988)

Coefficient of fluctuation (Whittaker 1975) in the bank vole population of Crabapple Island shows a decreasing trend from April through September. This is symptomatic for higher range of changes in numbers at the beginning of the breeding season than at the end of it (after Bujalska 1988)

stosunkowo wąskich granicach. Jakkolwiek spektakularne wydają się być szczyty liczebności, to warto sobie zdać sprawę, że wskaźnik fluktuacji (Whittaker 1975) określający zakres zmienności jest znacznie wyższy w kwietniu niż w lipcu czy we wrześniu (Rys 4). W kwietniu liczebność populacji jest funkcją zimowej śmiertelności - brak rozrodczości skazuje ją więc na pewnego rodzaju bierność. Dopiero początek sezonu rozrodczego przynosi możliwość aktywnego przeciwstawiania się zarówno zbyt szybkiemu wzrostowi, jak i gwałtownemu spadkowi liczebności. A wszystko dzięki fenomenowi jakim w drodze ewolucji stał się terytorializm dojrzałych samic.

Nie wątpię, że obraz który zaproponowałam nie jest ostateczny. Być może dalsze badania pozwolą go poprawić. Choć dane mi było korzystać z tradycji szkoły ekologicznej stworzonej przez Instytut Ekologii PAN, wiedzy zaczerpniętej z literatury i własnych obserwacji ktoś inny może zbudować inną figurę, niż proponowana przeze mnie oczomlonka. Pomimo rozwoju wiedzy i doskonalenia narzędzi badwawczych ciągle, nieomal po omacku, odkrywamy właściwości różnych form istnienia $\mathrm{Na}$ tury. I każdy z badaczy tworzy swój „program autorski” zostawiając własny ślad $w$ procesie poznania. 


\section{Piśmiennictwo}

Alcheikн B., 2001 - Trappability of Clethrionomys glareolus and Apodemus flavicollis inhabiting Crabapple Island, Masurian Lakeland, Poland - Pol. J. Ecol. 49: 407-425.

Andrewartha H. G., Birch L. C., 1954 - The distribution and abundance of animals - University of Chicago Press, Chicago.

BujALSKA G., 1973 - The role of spacing behaviour among females in the regulation of reproduction in in the bank vole - J. Reprod. Fert., suppl. 19: 463-472.

BUJALSKA G., 1985 - Fluctuations in an island bank vole population in thr light of the study on its organization - Acta theriol. 30: 3-49.

BUJALSKA G., 1988 - Life history consequences of territoriality in the bank vole (W: Evolution of life histories of mammals, Red. M. S. Boyce) - Yale University Press, Nev Haven, 75-79.

BuJalsKa G., 1991 - The ecology of territoriality in bank voles - Trends Ecol. Evol. 6: 300-301.

BujAlsKa G., 1994a - Minimum population of Clethrionomys glareolus (Schreber 1780) (W: Minimum animal populations , Red. H. Remmert) - Springer Verlag, Ecol. Stud. 106, Berlin, 119-130.

BUJALSKA G., 1994b - Female and male territoriality in the bank vole (W: Animal societies. Individual interactions and organization. Red. P. J. Jarman, A. Rossitier) - Kyoto Univ. Press, Kyoto: 56-69.

BUJALSKA G., 1997a - Winter reproduction of Clethrionomys glareolus (Schreber 1780) (W: Demographic variables in Crabapple Island population of the bank vole. Red. L. Grüm) Pol. ecol Stud. 21: 387-395.

Bujalska G., 1997b - Peak numbers of Clethrionomys glareolus (Schreber 1780) and mechanisms involved (W: Demographic variables in Crabapple Island population of the bank vole. Red. L. Grüm) - Pol. ecol. Stud. 21: 397-411.

BujalsKa G., 2000 - The bank vole population in Crabapple Island - Pol. J. Ecol. 48 Suppl.: $97-$ 106.

BUJALSKa G., GrÜM L., 1989 - Social organization of the bank vole (Clethrionomys glareolus, Schreber 1780) and its demographic consequences: a model - Oecologia (Berl.) 80: 70-81.

ChiтTY D., 1967 - The natural selection of self-regulatory behaviour in animal populations Proc. Ecol. Soc. Aust. 2: 51-78.

Elton C. S., 1924 - Periodic fluctuations in the numbers of animals: their causes and effects J. Exp. Biol. 2: 119-163.

FINERTY J. P., 1980 - The population ecology of cycles in small mammals - Yale Univ. Press, New Haven, London.

GLIwICZ J., 1980 - Islands populations of rodents: their organization and functioning - Biol. Rev. 55: $109-138$.

HANsSon L., 1978 - Small mammal abundance in relation to environmental variables in three Swedish forest phases - Studia Forest. Suec, 147: 1-40.

Ims R. A., 1988 - Spatial clumping of sexually receptive females induces space sharing among male voles 5 Nature 335: 541-543.

Jolly G. M., 1965 - Explicit estimates from capture-recapture data with both death and dilutionstochastic model - Biometrika 52: 225-247.

KaIKusalo A., 1972 - Population turnover and wintering of the bank vole, Clethrionomys glareolus (Schreber) in southern and central Finland - Ann. Zoologici Fennici 9: 219-224.

Krebs C. J., Myers J., 1974 - Populations cycles in small mammals - Adv. Ecol. Res. 8: 267399.

Moshin M., Dobrotvorsky A., Novikov E., Panov V., Ilyashenko V., Onischenko S., S Ergeev V., 2000 - Population dynamics of the bank vole (Clethrionomys glareolus Schreb.) in West Siberia - Pol. J. Ecol. 48 Suppl.: 107-112. 
Nicholson A. J., 1933 - The balance of animal populations - J. Anim. Ecol. 2: 132-178.

OstFELd R. S., 1990 - The ecology of territoriality in small mammals - Trends Ecol. Evol. 5: 411-415.

Petrusewicz K., 1966 - Dynamics, organization and ecological structure of population - Ekol. pol. A., 14: 413-436.

Pucek Z., Jędrzejewski W., Jędrzejewska B., 1993 - Rodent population dynamics in a primeval deciduous forest (Białowieża National Park) in relation to wheather, seed crop and predation - Acta theriol. 38: 199-232.

RatKIEwICZ M., BoRKowska A., 2000 - Multiple paternity and reproductive strategies in the bank vole (Clethrionomys glareolus): field and experimental data - Z. Säugetierkunde 65: 6-14.

ŚCIBOR-RYLSKA T., 1974 - Problemy życia i organizacji. Porządek i organizacja w przyrodzie Instytut Wydawniczy Pax, Warszawa.

Thompson D., 1812 - W: V. Hopwood red. 1971. Travels in Western North America, 1784-1812 - Macmillan, Toronto.

Volterra V., 1926 - Fluctuations in abundance of a species considered mathematically - Nature 118: 558-560.

WhitTAKER R. H., 1975 - Communities and ecosystems (2nd ed.) - Mac Millan-Collier, New York, London.

Wiger R., 1982 - Roles of self-regulatory mechanisms in cyclic populations of Clethrionomys with special reference to $C$. glareolus: a hypothesis - Oikos 38: 60-71.

ZEJDA J., 1981 - The small mammal community of a spruce monoculture - Acta Sc. Nat. Brno, 15: 1-31.

\section{The population dynamits of bank voles (Clethrionomys glareolus, Schreber 1780) and its significance for theory}

\section{SUMMARY}

This is an overview of long term studies (1966-1997) on the bank vole Clethrionomys glareolus (Photo 1) - population inhabiting Crabapple Island in NE Poland. The history of recognition of causes affecting population dynamics as well as variable interpretation of the facts comprising the theory of functional relations in that population are described. Meandering ideas can be illustrated by Fig. 1. The population dynamics (each year data on population numbers in April, July and October are shown) is presented in Fig. 2. The evidence is provided that the population exhibits a weak 3.8 year and much more clear 9.4 year cycle (Fig. 3).

The number of sexually mature females, that is those able to reproduce, has been relatively stable and independent of the population size or of the immature female numbers (Fig. 4). The reason is territoriality of mature females: the female territory (part of the female home range) cannot be visited by other mature females. A tendency toward territoriality was also noted among mature males, which numbers were limited by the availability of mature females, and therefore also relatively stable. Such a social system can be considered gynocentric. 
One of the results of stable numbers of reproductive females and survival rate increasing with population density is a decrease of fluctuation range in the breeding season, i.e., from April through September (Fig. 5). The results of those long term studies allow one to formulate the hypothesis that population density is not the target of regulation, but a result of interrelations between stable (regulated) reproduction and randomly changing survival rate. 